\title{
TERRITORIAL AND STATE ORGANIZATION
}

\section{By Claude R. Cook}

Iowa was a part of the Louisiana Purchase, and during the first 160 years following the voyage of Joliet and Marquette down the Mississippi river in 1673 it was the favorite hunting and trapping ground for a number of tribes of Indians. Among them were the Sac and Fox, the Winnebagoes, Pottawattamies Otoes, Omahas, Sioux, Ioways and Dakotas. The Mesquakie, now living in Iowa, returned after removal to Kansas.

Spanish and French monarchs had vague claims of jurisdiction over the region, but the standard of neither country had ever been set up permanently in any part of what is now Iowa. The United States closed out the French claim by purchase in 1803. After that local authority shifted frequently. For instance, Indiana territory was given jurisdiction, 1804. Louisiana territory was organized with St. Louis as the capitol, 1805 . In 1812 Missouri territory included Iowa. In 1821 when Missouri became a state, Iowa was left without government; so in 1834 the territory of Michigan, with the capitol at Detroit, was given jurisdiction. In 1836 Iowa became the major part of Wisconsin territory; in 1838 was created territory of Iowa; was authorized as a state in 1845, and organized as a state in 1846.

Of course, it is well known that Gen. Robert Lucas was appointed the first territorial governor. His service was during the years 1838-41. He twice had been governor of Ohio. When the state was organized, Ansel Briggs of Jackson county had been elected as the first governor of the state. The first capitol was established at Burlington in 1838, moved to Iowa City in 1841, where it remained until moved to Des Moines in 1857.

* An address by Curator Claude $R$. Cook before the members of the Department of Women's Affairs of the Des Moines Chamber of Commerce, November 2, 1948, at the Commodore Hotel, Des Moines. 
The early constitution under which the state had entered the Union had been hastily drawn in 1844, remodeled in 1846, discarded and a new constitution adopted in 1857, which has been amended several times since.

\section{South Solid From BeginNING}

One thing interesting to Iowa residents today, and something of great historical interest from. a political standpoint, should be emphasized. That is that at the time Iowa was admitted into the Union, there was a custom, though not a rule, that each time a free state was admitted into the Union a slave state also must be admitted. Florida and Iowa were admitted into the Union at the same time under this procedure. This was done so that the South could remain in control of the United States senate. So the "Solid South" was a stern reality before and has been since the inception of Iowa as a state.

\section{TERRITORIAL OFFICERS AND ElECTIONS}

The Organic Act of the territory of Iowa following the division of the territory of Wisconsin and the establishment of the territorial government of Iowa, provided for the organization of the Iowa territory and appointment or election of territorial officers. It authorized the president of the United States to nominate, and, with senate confirmation, appoint for the territory a governor, secretary, marshal, attorney, chief justice and two associate judges. The governor was appointed for a term of three years, while the secretary, marshal and attorney were for four, and all subject to removal by the president. Chief justice and associate judges were appointed for four years, as the Organic Act of the territory of Wisconsin had also provided.

This act gave the governor authority to set the time, place and manner of conducting the first election of members to the legislative assembly and delegate to congress. The governor was required to proclaim the election of the successful candidates. If there was a tie, the governor was to call a new election, and the legisla- 
tive assembly was empowered to provide by law for subsequent elections. The members of the council and the delegate to congress were to serve two years; the members of the house of representatives, for one.

Accordingly Robert Lucas, the first governor of the territory, on August 15, 1838, issued a proclamation calling for the election of members of the legislative assembly and a delegate to congress on the second Monday of September, 1838. The sheriff of each county advertised the election in one or more newspapers, or posted five written or printed notices in each election precinct, and this election was to be conducted, as far as the Iowa Organic Act was not infringed upon, in accordance with the general election law of the territory of Wisconsin of January, 1838.

\section{Territorial General Elections}

An act providing for general elections in the territory was approved January 25, 1839 . It seems to have been copied from the Wisconsin election law of 1838. This general election law set the first Monday of August of each year for the holding of the general election. Then on January 15, 1840, the act to provide for an extra session of the legislature became a law and named the first Monday of October as the date for election in 1840 only. Subsequent elections were to be held on the first Monday in August. The general election of 1843 required that the election be held on the first Tuesday in October; but on January 29, 1844, provision was again made for holding general elections on the first Monday in August.

The counties of the territory were divided into election precincts and place of the election given in notices of election. In a county divided into townships, the place of voting at general and township elections was the same. The Iowa law of 1839 required a clerk to make out notices fifty days before a special election with no provision for general election. In 1843 an amendment required the clerks to perform the same duties with 
reference to general election and was included in the general election law. but singularly enough made no provision for a special election.

The election notices were to be posted by the sheriff thirty days before general election and eight days before a special election. If there were no special precincts provided for, by law, one election notice was posted at the house where the election was to be held, and the other two notices in public places nearby.

The board of county commissioners at their April meeting appointed three electors as judges to serve for each precinct, to serve at all elections until others were appointed. These were notified by the clerk of the board. Then the judges appointed two electors to serve as election clerks.

Clerks of the county boards of commissioners of the different counties were required to examine the election returns and send a certified abstract to the governor. The governor then issued his proclamation giving the result.

\section{LOCAL AND COUNTY OFFICERS}

Local officers and county officers were authorized under the Organic Act of 1838, except judicial officers, justices of the peace, sheriffs, and clerks of court. The exceptions were to be nominated and, by and with the advice and consent of the legislature, appointed by the governor, as were also other civil officers whose election was not otherwise provided for.

Territorial laws with the provisions of the act were passed during the first session of the legislative assembly, and these authorized the election of the necessary number of constables for each county and assessor, three county commissioners, a recorder, public administrator, and county surveyor. After township governments were provided for, constables were elected at the township election. 


\section{ObJect to Veto Power}

Considerable friction between the executive and first legislature arose over the governor's exercise of the veto power. The president was even petitioned for his removal. Consequently, in 1839, congress amended the Iowa Organic Act cutting down the governor's appointive power, and by this amendment the legislative Assembly was given authority to provide for election of sheriffs, judges of probate, justices of the peace, and county surveyors. The legislative assembly in its act also authorized the election of coroners, treasurers, clerks of the board of county commissioners, collectors and inspectors of weights and measures. County commissioners and judges of probate were elected for three years. Surveyors, sheriffs, commissioners, clerks, coroners, recorders, two years; public administrators, assessors, county treasurers, and collectors, one year. The first election was held in accordance with the Wisconsin law. After the first election, county officers were elected at the general election under the same regulations governing election of territorial officers.

\section{Creation of TOWNShips AUthorized}

The organization of townships was also authorized by the Organic Act of the territory of Iowa. The legislative assembly was given power to provide for subsequent elections. In his message to the First Legislative Assembly, Governor Lucas called attention to the importance of township organization, and the necessity of providing for election of township officers. Since the legislative assembly took no action the governor renewed his suggestion to the Second Legislative Assembly, indicating that township organization was intimately connected with the public school system and building of public roads, also made local business more convenient and less expensive.

On January 10, 1840, "an act to provide for the organization of townships" was approved. It also provided for the election of necessary officers. 
This required the township trustees to serve as judges at general elections. This was subsequently amended in 1842 to require the township trustees to be elected at both general and special elections.

The township meetings elected a clerk, three trustees, two overseers of the poor, a sufficient number of supervisors of highways, two constables, a township treasurer, and two fence viewers. On February 17, 1842, the law was passed, providing for the election of three fence viewers.

\section{APPOINTMENT OF Election JUdges}

The general election law of 1843 also authorized county commissioners to appoint three judges of election in each precinct in counties not divided into townships, while the township trustees served as judges at all elections held in organized counties. In undivided counties organized, the township clerk, the person appointed by the township clerk and approved by the election judges, served as election clerk. In case of vacancies, the judges who were present appointed justices of the peace; if no justices were present electors were chosen. If there were neither election judges nor justices present at the time of opening at the polls, the electors present selected three people from their own number to act as judges of election, and the justices or electors thus chosen were to have the same powers, as if regularly authorized.

of course, there was the usual oath or affirmation. If there were no judges or justices present, the election judges administered the oath to each other and the clerk. The one administering, signed the entry into the poll book.

Polls were open from 9:00 a. m. to 6:00 p. m., but might be kept open until 9:00 p. $\mathrm{m}$. if the judges felt it necessary. And in case there were no judges on hand for the opening, polls could open at any hour before the time of closing. A thirty-minute warning was given before the polls were to be closed. Paper ballots were marked by the elector and folded so the judges could 
not see them. Then, as now, the ballot was handed to the judge to put it in the ballot box and the clerks took down the name of the voters.

After canvassing the votes, the clerk entered in the books full names of all persons voted for offices, for which they had received the vote and the number. This list was certified by the judges and attested by the clerks. One of the poll books was sealed and delivered to the clerk of the board of commissioners. If the seal was broken, the judge or clerk entrusted with it could be fined $\$ 500$.

\section{Trustees Became Fence VIEWERS}

In 1845 , June 5 , to be exact, legislation was adopted requiring township trustees to attend the duties of the fence viewers and overseers of the poor. Two justices of the peace were elected at the township meeting, unless the county was not divided into townships and then two justices were elected for each precinct at the general election for two-year terms. Other township officers served one year and the township election was held every year on the first Monday of April. The first election, however, which now is of interest for our purpose, was determined by the board of county commissioners. After the first election, the election place was determined by the township trustees and notice was served twenty days before the election designating the time, the place, and the offices to be filled. When eight or more electors had assembled, they elected from their own number by ballot, a chairman to preside over the meeting and two judges of election. The latter qualifying by oath. Township clerks seem at first to have served as clerks.

The Act of January 10,1840, seems to have required the polls be open from 10:00 until 4:00. In 1845 this was amended to open between 8:00 and 10:00 and close at 6:00 p. m., and if the number of electors required for legal election failed to attend the polls between 10:00 
a. m. and 4:00 p. m. on election day trustees appointed all township officers for the year. Vacancies were filled by the board of trustees.

\section{MUNICIPAL ELECTIONS}

Muncipal elections came into being during the territorial period. Villages and towns were incorporated and government provided for by special charter. The officers usually elected by ballot for a term of one year were president, a recorder and a board of trustees or council from three to five members. The first Monday of May was a favorite election day, and the polls were usually open from 10:00 a. m. until 5:00 p. m.

The division of cities into wards was governed by regulations quite similar to those for town elections.

In some instances, however, after municipal elections came into existence the township in which the municipality was located sometimes continued to control the city election set up. An instance is the city of Grinnell, where for ten years after the establishment of the municipality the township in which the town is situated, township trustees set up the city election officials. This probably prevailed in other instances in the state.

First Delegate to CoNGress

The first general election to select a delegate to Congress was held on September 10, 1838, under a proclamation by Robert Lucas, first governor of the territory of Iowa. Among the candidates were George W. Jones, who previously had served in similar capacity as delegate from Wisconsin territory, and William W. Chapman, who was elected and held the office for two years. The next election, the latten being 1840, the transition year in Iowa territorial politics, was the year of the HarrisonTyler campaign. This has been called the most enthusiastic and picturesque campaign in Iowa history. Augustus Caesar Dodge was elected delegate for the one-year term in 1840. After that election of territorial delegates came in the odd years. Dodge held the office of territorial delegate until Iowa was admitted into the Union, December $28,1846$. 


\section{First State Election}

Anticipating the admission of Iowa into the Union, the dispute over state boundaries having been settled, congress passed an act August 4, 1846, providing "that until the next census apportionment be made the state of Iowa shall be entitled to two representatives in the House of Representatives in the United States." It became the duty of the legislature of Iowa to divide the state into two congressional districts. In order that representation in congress would be immediately upon its formal admission into the Union, it was provided in the state constitution that the first election of representatives should be held at the same time as the election of the members of the general assembly and other state officers. But, the state had not been districted in time for the election of that year, so Iowa's first congressmen were elected at large instead of by districts.

On September 9, 1846 Gov. James Clark, now territorial governor following John Chambers, and who was the third territorial governor, issued a proclamation directing the first state election to be held on Monday, October 26,1846 . It provided that the two representatives in congress were to be chosen at this time, and various state officers to be elected, including members of the state senate and house of representatives. The other state officers to be chosen were governor, auditor, treasurer and secretary of state.

Iowa was ushered into the Union under control of the Democratic party, for in the election of October 26, 1846 the entire Democratic ticket was elected against the Whigs, with Ansel Briggs, low man with only 161 majority. The first congressmen were Shepperd Leffler and S. C. Hastings.

The first United States senators were Augustus Caesar Dodge and George W. Jones. But they were elected by the legislature December 7, 1848, after two years of unrepresented statehood in the United States senate. They were presented in the senate December 26, 1848. So ended a two-year bitter political struggle to choose United States senators. 
Copyright of Annals of Iowa is the property of State of Iowa, by \& through the State Historical Society of Iowa and its content may not be copied or emailed to multiple sites or posted to a listserv without the copyright holder's express written permission. However, users may print, download, or email articles for individual use. 